\title{
Influence of nitrogen, environment, and cultivars on the industrial quality of wheat
}

\author{
Influência do nitrogênio, ambiente e cultivares na qualidade \\ industrial de trigo
}

\author{
Raphael Rossi Silva'; Claudemir Zucareli²; Inês Cristina de Batista Fonseca²; \\ Diego Gazola ${ }^{3 *}$; Carlos Roberto Riede ${ }^{4}$
}

\begin{abstract}
The quality of wheat is a pre-eminent factor in the criteria for commercialization of this cereal, and several parameters contribute to the evaluation of wheat quality. The objective of this study was to verify the effects of nitrogen fertilization on the cover and the environment for wheat cultivars and the effects on the industrial quality of the grain. Furthermore, we sought to identify correlations between the parameters of industrial quality. Experiments were conducted in Londrina for 2 years, in two distinct environments (A1 and A2). The experimental design was a randomized complete block design with four replications. The cultivars IPR Catuara TM, BRS Gaivota, Quartzo, and CD 120 were evaluated with different forms of nitrogen management: $\mathrm{N} 1$, without $\mathrm{N}$ in coverage; $\mathrm{N} 2,60 \mathrm{~kg} \mathrm{ha}^{-1}$ of $\mathrm{N}$ in the form of urea at the beginning of tillering; $\mathrm{N} 3,80 \mathrm{~kg} \mathrm{ha}^{-1}$ of N in urea formulation $\left(60 \mathrm{~kg} \mathrm{ha}^{-1}\right.$ in tillering and $20 \mathrm{~kg} \mathrm{ha}^{-1}$ in booting); $\mathrm{N} 4,100 \mathrm{~kg} \mathrm{ha}^{-1}$ of $\mathrm{N}$ in the form of urea $\left(60 \mathrm{~kg} \mathrm{ha}^{-1}\right.$ in tillering and $40 \mathrm{~kg} \mathrm{ha}^{-1}$ in booting); $\mathrm{N} 5,80 \mathrm{~kg} \mathrm{ha}^{-1}$ of $\mathrm{N}$ ( $60 \mathrm{~kg} \mathrm{ha}^{-1}$ of $\mathrm{N}$ in the form of urea at the beginning of tillering, and $20 \mathrm{~kg} \mathrm{ha}^{-1}$ of $\mathrm{N}$ in the form of ammonium sulfate in booting); N6, $100 \mathrm{~kg} \mathrm{ha}^{-1}$ of $\mathrm{N}$ ( $60 \mathrm{~kg} \mathrm{ha}^{-1}$ of N in the form of urea at the beginning of tillering, and $40 \mathrm{~kg} \mathrm{ha}^{-1}$ of $\mathrm{N}$ in the form of ammonium sulfate in booting). Further, we evaluated grain yield, protein content, sedimentation volume with sodium dodecyl sulfate, and parameters of alveograph and farinograph. Nitrogen fertilization did not influence industrial quality parameters. The stability of the mass was influenced by the isolated effects of cultivars and the environment. The interaction of cultivars and environments influenced the parameters of alveograph and water absorption of the mass. The higher the protein content, the lower the stability of the mass, independent of the cultivar.
\end{abstract}

Key words: Farinograph. Gluten strength. Triticum aestivum L. Protein content. Nitrogen management.

\section{Resumo}

A qualidade do trigo é fator preponderante nos critérios para comercialização desse cereal e diversos parâmetros contribuem na avaliação de sua qualidade. O objetivo deste estudo foi verificar o efeito da adubação nitrogenada de cobertura e do ambiente, em cultivares de trigo e seus efeitos na qualidade industrial do grão, a fim de proporcionar melhorias para mudança de classe do cultivares, bem como identificar correlações entre os parâmetros de qualidade industrial. Foram conduzidos experimentos em Londrina em dois anos, caracterizando dois ambientes (A1 e A2). O delineamento experimental

1 Pesquisador, Dr., Tropical Melhoramento e Genética, TMG, Londrina, PR, Brasil. E-mail: rossi.raphael@outlook.com

2 Profs., Drs., Departamento de Agronomia, Centro de Ciências Agrárias, Universidade Estadual de Londrina, UEL, Londrina, PR, Brasil.E-mail: claudemircca@uel.br; inescbf@uel.br

3 Dr. em Agronomia, UEL, Londrina, PR, Brasil. E-mail: gazolad@gmail.com

${ }^{4}$ Pesquisador, Dr., Instituto Agronômico do Paraná, IAPAR, Londrina, PR, Brasil. E-mail: criede@iapar.br

* Author for correspondence 
utilizado foi o de blocos ao acaso em parcelas subdivididas, com quatro repetições. Foram avaliadas as cultivares IPR Catuara TM, BRS Gaivota, Quartzo e CD 120 em diferentes formas de manejo do nitrogênio em cobertura: N1 - sem N em cobertura; $\mathrm{N} 2-60 \mathrm{~kg} \mathrm{ha}^{-1}$ de $\mathrm{N}$ na formulação de ureia no início do perfilhamento; $\mathrm{N} 3-80 \mathrm{~kg} \mathrm{ha}^{-1}$ de $\mathrm{N}$ na formulação de ureia, $\left(60 \mathrm{~kg} \mathrm{ha}^{-1}\right.$ no perfilhamento e 20 $\mathrm{kg} \mathrm{ha}^{-1}$ no emborrachamento); N4 - $100 \mathrm{~kg} \mathrm{ha}^{-1}$ de N na formulação de ureia $\left(60 \mathrm{~kg} \mathrm{ha}^{-1}\right.$ no perfilhamento e $40 \mathrm{~kg} \mathrm{ha}^{-1}$ no emborrachamento); N5 - $80 \mathrm{~kg} \mathrm{ha}^{-1}$ de N (60 kg ha-1 de N na formulação de ureia no início do perfilhamento, e $20 \mathrm{~kg} \mathrm{ha}^{-1}$ de $\mathrm{N}$ na formulação de sulfato de amônio no emborrachamento); $\mathrm{N} 6-100 \mathrm{~kg} \mathrm{ha}^{-1}$ de $\mathrm{N}\left(60 \mathrm{~kg} \mathrm{ha}^{-1}\right.$ de N na formulação de ureia no início do perfilhamento, e $40 \mathrm{~kg}$ $\mathrm{ha}^{-1}$ de $\mathrm{N}$ na formulação de sulfato de amônio no emborrachamento). Foram realizadas avaliações da produtividade de grãos, do teor de proteínas, do volume de sedimentação com dodecil sulfato de sódio e dos parâmetros de alveografia e farinografia. A adubação nitrogenada não influencia os parâmetros de qualidade industrial. A estabilidade da massa é influenciada pelos efeitos isolados de cultivar e ambiente. A interação cultivares e ambientes influencia os parâmetros de alveografia e absorção de água da massa. Quanto maior o teor protéico, menor a estabilidade da massa, independentemente da cultivar. Palavras-chave: Farinografia. Força de glúten. Teor de proteínas. Triticum aestivum L. Manejo do nitrogênio.

\section{Introduction}

Wheat (Triticum aestivum L.) is one of the main cereals grown worldwide, and its importance is related to the diversity of products it can produce. Consequently, it is widely used in industry, and for human and animal food. Brazilian annual production is of wheat is approximately 5 million tons, with the State of Paraná being the largest producer, producing more than $50 \%$ of the total wheat produced in the entire country (CONAB, 2018).

The quality of wheat is a prominent factor in the criteria for marketing this cereal, and various parameters contribute to the evaluation of its quality. The market demands cultivars that ensure quality standards for the industry and the end user. Various parameters contribute to the evaluation of the quality of wheat including: mass of hectoliter $(\mathrm{MH})$, housand kernel weight (TKW), protein content (PC), sedimentation test with sodium dodecyl sulfate (SSDS), mass stability (EST), dough water absorption (AAM), gluten strength (W), tenacity $(\mathrm{P})$, and extensibility (L). These parameters are influenced by the interaction between genotype and the environment and the management of the culture (GARRIDO-LESTACHE et al., 2004; CAZETTA et al., 2008; PINNOW et al., 2013).

Among the environmental effects, temperature has a significant effect on the quality parameters, mainly on TP (LABUSCHAGNE et al., 2009). Thus, when wheat is subjected to high temperature, the grain mass is affected, because starch is the largest constituent of grain. Conversely, there is an increase in protein content under high temperature conditions, which can result in an increase in gluten strength (TRIBOI; TRIBOI-BLONDEL，2002; LABUSCHAGNE et al., 2009), thus, improving baking quality. When moderate water deficits occur during grain filling, there are improvements in the mass of grains, starch composition, and baking quality of harvested wheat (HAJHEIDARI et al., 2007; XING et al., 2009).

In addition to environmental factors, nitrogen fertilization influences the quality of the wheat, because the W, TP, and the relationship between the tenacity and extensibility can change (CAZETTA et al., 2008). However, the efficiency of the application of urea, the main source of $\mathrm{N}$, depends on the occurrence of suitable climatic conditions, mainly rainfall (GAZOLA et al., 2017). Varga and Svecnjak (2006) reported that the application of $\mathrm{N}$ in the form of urea close to anthesis causes a reduction in W. Equally, excess nitrogen fertilization (above $300 \mathrm{~kg} \mathrm{ha}^{-1}$ of $\mathrm{N}$ ) reduces the proportion of high molecular weight glutenins (YUE et al., 2007). A negative correlation is frequently observed between TP and grain yield in wheat (GUARDA et al., 2004; 
ŠÍP et al., 2013). On the other hand, despite this negative correlation, it is possible to increase the productivity of grains concomitant with the increase in TP (PINNOW et al., 2013).

The use of the farinograph (EST and AAM) and alveograph (W, P, L, and $\mathrm{P} / \mathrm{L}$ ) is considered the standard technique to predict the technological quality and end-use on the wheat market and in genetic improvement programs. Generally, the measures obtained in these devices are dependent on TP. The increase of TP is positively correlated with the volume of bread; however, when TP is very high, W can decrease. Despite the knowledge of these relations between PT and the farinograph and alveograph parameters, an in-depth study of these relations in cultivars used in Brazil is important because of the effect of TP on other technological quality parameters that vary, primarily, because of genotypic effects (FOWLER; KOVACS, 2004).

Therefore, the objective of this study was to investigate the effects of nitrogen fertilization, the environment, and cultivars on the industrial quality of wheat, to provide improvements that could change the class of cultivars, and to identify and quantify the correlations between direct and indirect measures of industrial quality of wheat.

\section{Material and Methods}

The experiments were conducted in the field, during two agricultural years in Londrina $\left(23^{\circ} 22^{\prime} 09^{\prime \prime} \mathrm{S}, 51^{\circ} 10^{\prime} 13^{\prime \prime} \mathrm{W}\right.$ at $549 \mathrm{~m}$ altitude). The predominant climate is of type Cfa and soil is classified as distroferric red Latosol (SANTOS et al., 2013). The experimental design was a randomized complete block design with four replications, using two replicates for industrial quality analyses. Four wheat cultivars (main plot) were tested with six nitrogen management forms (subplots) in two environments (site and year grouped). Sowing was mechanized in a no-tillage system on soybean straw on April 16th (A1) and April 20th (A2). Each experimental unit (subplot) was composed of six $0.17 \mathrm{~m}$ spaced rows $7 \mathrm{~m}$ in length with a floor area of $5.1 \mathrm{~m}^{2}$; the distance between each subplot was $1 \mathrm{~m}$. The seeds were treated with imidacloprid (Gaucho FS) at a dose of $70 \mathrm{~mL}$ (p.c.) per $100 \mathrm{~kg}$ of seeds. The base fertilization was $300 \mathrm{~kg} \mathrm{ha}^{-1}$ in a 10-30-10 formulation.

The cultivars tested were IPR Catuara TM, BRS Gaivota, Quartzo, and CD 120 that are widely cultivated and marketed in the region. Their genealogies, agronomic, and technologic characteristics are presented in Table 1. The environments were coded as environment A1 (Londrina, year 1) and environment A2 (Londrina, year 2). Nitrogen management forms consisted of the following: N1, without $\mathrm{N}$ in coverage; N2, $60 \mathrm{~kg} \mathrm{ha}^{-1}$ of $\mathrm{N}$ in the form of urea applied at the beginning of tillering; $\mathrm{N} 3,80 \mathrm{~kg} \mathrm{ha}^{-1}$ of $\mathrm{N}$ in form of urea, $60 \mathrm{~kg} \mathrm{ha}^{-1}$ and $20 \mathrm{~kg} \mathrm{ha}^{-1}$ were applied at the beginning of tillering and booting, respectively; $\mathrm{N} 4,100 \mathrm{~kg} \mathrm{ha}^{-1}$ of $\mathrm{N}$ in form of urea, $60 \mathrm{~kg} \mathrm{ha}^{-1}$ and $40 \mathrm{~kg} \mathrm{ha}^{-1}$ were applied at the beginning of tillering and booting, respectively; N5, $80 \mathrm{~kg} \mathrm{ha}^{-1}$ of $\mathrm{N}$, with $60 \mathrm{~kg} \mathrm{ha}^{-1}$ of $\mathrm{N}$ in the form of urea at the beginning of tillering, and $20 \mathrm{~kg} \mathrm{ha}^{-1}$ of $\mathrm{N}$ in the form of ammonium sulfate during booting; N6, 100 $\mathrm{kg} \mathrm{ha}^{-1}$ of $\mathrm{N}$, with $60 \mathrm{~kg} \mathrm{ha}^{-1}$ of $\mathrm{N}$ in the form of urea at the beginning of the tillering, and $40 \mathrm{~kg} \mathrm{ha}^{-1}$ of $\mathrm{N}$ in the form of ammonium sulfate during booting. In environment $\mathrm{A} 1$, after the nitrogen coverage fertilization, the experiment was irrigated with a water blade of approximately $15 \mathrm{~mm}$. The climatic conditions of each environment are shown in Figure 1 , and the chemical characteristics of the soil are shown in Table 2.

The following evaluations were conducted: a) grain yield after mechanical harvesting, was determined by grain mass in each experimental unit estimated in $\mathrm{kg} \mathrm{ha}^{-1}$, at $13 \%$ humidity; b) protein content (\%) was determined by near infrared reflectance spectrophotometry (NIR) using the FOSS NIRSYSTEM model 6500 apparatus. The NIR calibration curves were constructed using the Kjeldahl method, in triplicate; c) the sedimentation 
test with sodium dodecyl sulfate $(\mathrm{mL})$ was conducted according to the methodology proposed by Dick and Quick (1983); d) the viscoelastic characteristics of the wheat flour were determined according to AACC methods, using a Chopin alveograph, model NG, with 250 grams of flour and a volume of $129.4 \mathrm{ml}$ of water, corrected on a $14 \%$ moisture basis. The parameters obtained in the alveograms were tenacity $(\mathrm{P})$, which measures the maximum pressure exerted on the dough expansion $(\mathrm{mm})$; extensibility (L), which measures the length of the curve $(\mathrm{mm})$ and dough deformation energy (W), which corresponds to the mechanical work required to expand the bubble to rupture, expressed in $10^{-4} \mathrm{~J}$. The characteristics of the dough during the mixing were determined according to AACC methods, using a Brabender Farinograph, model E, with $50 \mathrm{~g}$ of wheat flour. The parameters evaluated were water absorption, which indicated the quality of the flour reflected by the swelling capacity of the gluten and the damaged starch content, and stability, defined as the time difference between the point at which the top of the curve intersected the midline of 500 and the point of the curve leaving the line. Two of the four field replicates were used in the analyses.

Table 1. Genealogy, agronomic, and technologic characteristics of the cultivars tested.

\begin{tabular}{|c|c|c|c|c|}
\hline Cultivars & Genealogy & Cycle & $\begin{array}{l}\text { Gluten strength } \\
(10-4 \mathrm{~J})\end{array}$ & $\begin{array}{l}\text { Commercial } \\
\text { Class }\end{array}$ \\
\hline IPR Catuara TM & LD 875/IPR 85 & Early & 340 & Breeder \\
\hline BRS Gaivota & $\begin{array}{l}\text { BR 35/Klein H } 2860 \text { U 12100// } \\
\text { Sonora 64/BR } 23\end{array}$ & Medium & 290 & Bread \\
\hline Quartzo & Onix/Avante & Medium & 270 & Bread \\
\hline CD 120 & RUBI/CD105 & Medium & 111 & Basic \\
\hline
\end{tabular}

Source: Meeting of the Brazilian Commission for Wheat and Triticale, 2011.

Figure 1. Rainfall and minimum and maximum temperature related to environment 1, Londrina, Year 1 (A) and environment 2, Londrina, Year 2 (B).

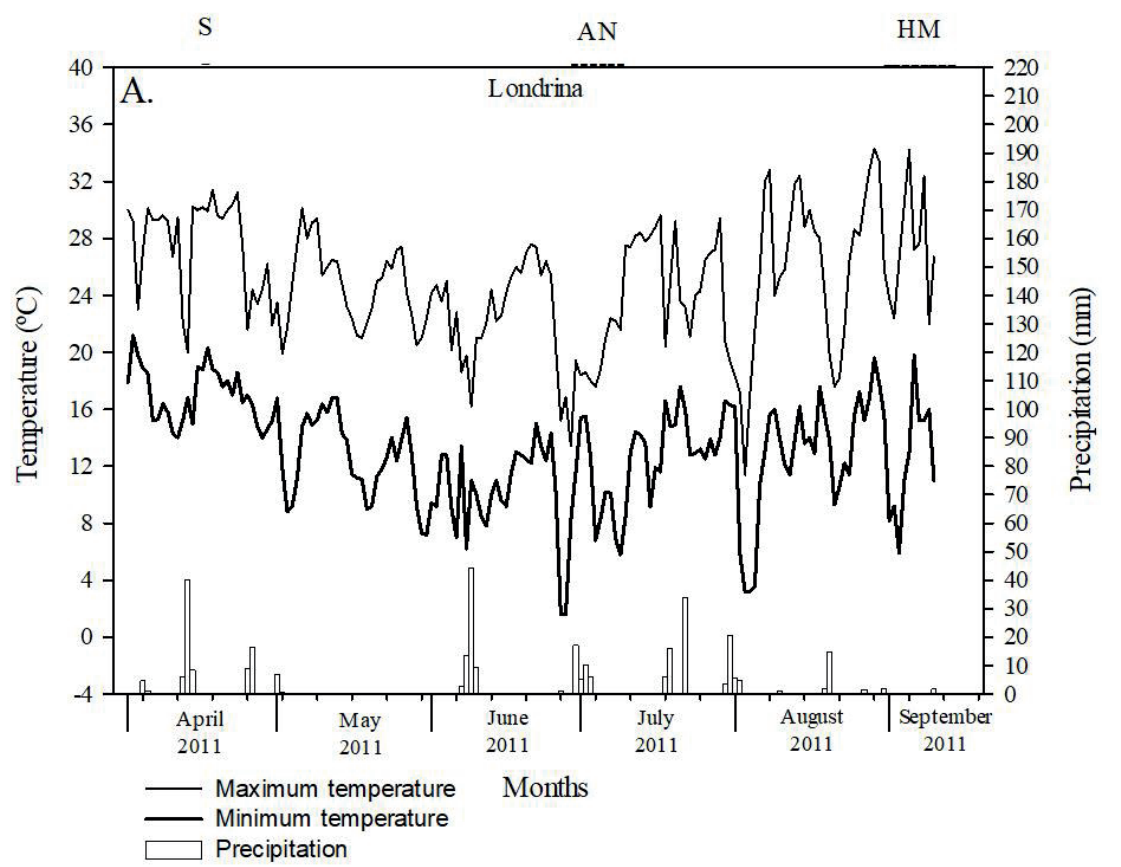


Table 2. Chemical characteristics of the soil in the 0-20 cm layer, in the two environments studied. Londrina/Paraná.

\begin{tabular}{lccc}
\hline \multirow{2}{*}{ Characteristics } & \multirow{2}{*}{ Unit } & \multicolumn{2}{c}{ Environments } \\
\cline { 2 - 4 } & & $\mathrm{A} 1$ & $\mathrm{~A} 2$ \\
\hline $\mathrm{P}$ & $\mathrm{mg} \mathrm{dm}^{-3}$ & 21.1 & 24.5 \\
$\mathrm{pH}\left(\mathrm{CaCl}_{2}\right)$ & & 5.10 & 5.30 \\
$\mathrm{Al}$ & & 0 & 0 \\
$\mathrm{H}+\mathrm{Al}$ & & 6.20 & 5.34 \\
$\mathrm{Ca}$ & $\mathrm{cmolc} \mathrm{dm}^{-3}$ & 5.72 & 5.25 \\
$\mathrm{Mg}$ & & 2.26 & 2.87 \\
$\mathrm{~K}$ & & 0.18 & 0.88 \\
$\mathrm{SB}$ & & 8.16 & 9.00 \\
$\mathrm{CTC}$ & & 14.36 & 14.34 \\
$\mathrm{~V}$ & & 56.82 & 62.76 \\
$\mathrm{Salt}$ & & 0 & 0 \\
$\mathrm{OM}$ & & 1.7 & 1.9 \\
\hline
\end{tabular}

Analysis of variance (ANOVA) was performed and significant effects were analyzed by comparison of means using Tukey's test at 5\% significance. Associations between the response variables were analyzed using Pearson correlation at 5\% significance. The statistical software used was $\mathrm{R}(\mathrm{R}$ DEVELOPMENT CORE TEAM, 2009).

\section{Results and Discussion}

In the combined variance analysis (Table 3), the isolated effects of environments and cultivars were significant only for the stability of the dough, whereas the other quality characteristics were significantly influenced by the interaction of cultivars and the environment $\left(\mathrm{A}^{*} \mathrm{C}\right)$. The effects of cultivars were responsible for most of the total variance in $\mathrm{W}, \mathrm{P}$, and $\mathrm{AAM}$. Although $\mathrm{A}^{*} \mathrm{C}$ was significant, this effect was probably less important in relation to the isolated effects of the cultivars and environments; however, $\mathrm{A}{ }^{*} \mathrm{C}$ was largely dependent on the experimental locations (HRISTOV et al., 2010). Therefore, a larger number of environments could result in greater importance in the total variance for the $\mathrm{A}^{*} \mathrm{C}$ effect.
The environment significantly influenced the W of the cultivar BRS Gaivota, whereas the other cultivars were not influenced by the environment (Table 4). In environment A1, the cultivar IPR Catuara TM displayed the highest $\mathrm{W}$, whereas the Quartzo and CD 120 cultivars had the lowest W. In environment A2, the cultivars Ipr Catuara TM and CD 120 exhibited the highest and lowest W, respectively.

The P of the cultivar IPR Catuara TM was not influenced by the environment, contrary to that of the other genotypes. Environment A1 yielded higher values of $\mathrm{P}$ for the cultivars that were influenced by the effect of the environment. In the climatic conditions of A1, the cultivars IPR 1 Catuara TM and Quartzo yielded the highest P, whereas in A2 only the cultivar IPR Catuara TM was superior. The L of the cultivars Quartz and CD 120 were influenced by the environment. In the A1 environment, the cultivars Quartz and CD 120 presented the lowest values of $\mathrm{L}$ and in the environment A2 the Quartz cultivar presented the lowest L. 
Table 3. Joint analysis of variance of alveograph and farinograph parameters of wheat cultivars under different forms of nitrogen management and environmental conditions.

\begin{tabular}{|c|c|c|c|c|c|c|}
\hline F.V. & $\mathrm{W}$ & $\mathrm{P}$ & $\mathrm{L}$ & $\mathrm{P} / \mathrm{L}$ & AAM & EST \\
\hline \multicolumn{7}{|l|}{ Blocks } \\
\hline QM (2 $\left.{ }_{\mathrm{GL}}\right)$ & 3767.3 & 43.8 & 145.5 & 0.03 & 1.97 & 52.9 \\
\hline p-value & 0.27 & 0.81 & 0.65 & 0.78 & 0.36 & 0.40 \\
\hline \multicolumn{7}{|c|}{ Environments (A) } \\
\hline $\mathrm{QM}\left(1_{\mathrm{GL}}\right)$ & 2229.2 & 5635.8 & 22262.1 & 9.36 & 33.38 & 3061.1 \\
\hline $\mathrm{p}$-value & 0.36 & $<0.01$ & $<0.01$ & $<0.01$ & $<0.01$ & $<0.01$ \\
\hline \multicolumn{7}{|l|}{ Cultivars (C) } \\
\hline $\mathrm{QM}\left(3_{\mathrm{GL}}\right)$ & 337600.9 & 21433.4 & 10087.9 & 7.93 & 647.3 & 459.8 \\
\hline p-value & $<0.01$ & $<0.01$ & $<0.01$ & $<0.01$ & $<0.01$ & 0.01 \\
\hline \multicolumn{7}{|c|}{ Environment $\mathrm{X}$ Cultivars $\left(\mathrm{A}^{*} \mathrm{C}\right)$} \\
\hline $\mathrm{QM}\left(3_{\mathrm{GL}}\right)$ & 15767.2 & 968.7 & 2657.4 & 2.22 & 21.2 & 29.4 \\
\hline p-value & 0.02 & 0.05 & 0.02 & $<0.01$ & $<0.01$ & 0.64 \\
\hline \multicolumn{7}{|l|}{ Residual } \\
\hline $\mathrm{QM}\left(6_{\mathrm{GL}}\right)$ & 2284.1 & 197.7 & 360.1 & 0.1194 & 1.61 & 49.5 \\
\hline \multicolumn{7}{|l|}{ Nitrogen $(\mathrm{N})$} \\
\hline $\mathrm{QM}\left(5_{\mathrm{GL}}\right)$ & 2099.3 & 143.8 & 749 & 0.39 & 2.67 & 2.7 \\
\hline p-value & 0.53 & 0.63 & 0.20 & 0.09 & 0.28 & 0.99 \\
\hline \multicolumn{7}{|c|}{ Environment $\mathrm{X}$ Nitrogen $\left(\mathrm{A}^{*} \mathrm{~N}\right)$} \\
\hline $\mathrm{QM}\left(5_{\mathrm{GL}}\right)$ & 672 & 199.2 & 98.2 & 0.11 & 1.6 & 6.6 \\
\hline p-value & 0.90 & 0.49 & 0.91 & 0.51 & 0.49 & 0.98 \\
\hline \multicolumn{7}{|c|}{ Cultivars x Nitrogen $\left(\mathrm{C}^{*} \mathrm{~N}\right)$} \\
\hline $\mathrm{QM}\left(15_{\mathrm{GL}}\right)$ & 1507 & 240.8 & 392.9 & 0.307 & 1.62 & 29.4 \\
\hline p-value & 0.76 & 0.43 & 0.49 & 0.12 & 0.54 & 0.64 \\
\hline \multicolumn{7}{|l|}{$A * C * N$} \\
\hline $\mathrm{QM}\left(15_{\mathrm{GL}}\right)$ & 1466.2 & 121.2 & 166.3 & 0.07 & 2.24 & 26.5 \\
\hline p-value & 0.77 & 0.79 & 0.89 & 0.81 & 0.36 & 0.85 \\
\hline \multicolumn{7}{|l|}{ Residual } \\
\hline $\mathrm{QM}\left(41_{\mathrm{GL}}\right)$ & 1888.1 & 199.3 & 161.8 & 0.109 & 2.22 & 18.3 \\
\hline Mean & 328 & 102 & 99 & 1.2 & 60.6 & 14.9 \\
\hline CV $1(\%)$ & 14.5 & 13.7 & 19 & 28.6 & 2.1 & 47 \\
\hline CV $2(\%)$ & 13.2 & 13.7 & 12.7 & 27.4 & 2.4 & 28 \\
\hline
\end{tabular}

Legend: W, gluten strength; P, tenacity; L, extensibility; AAM, dough water absorption; EST, dough stability.

Temperature, in particular, was responsible for several physiological changes in the accumulation of wheat grain reserves (GAJU et al., 2009), which interact in a complex way, and modify the technological quality (TRIBOI; TRIBOIBLONDEL, 2002). The optimum temperature from anthesis to physiological maturation to obtain a high grain weight should be approximately $16^{\circ} \mathrm{C}$. In contrast to starch, the protein content increased with high temperatures (TRIBOI; TRIBOI-BLONDEL, 2002; LABUSCHAGNE et al., 2009), which confirms the results obtained, especially for the cultivar BRS Gaivota. 
Although high temperatures (above $32^{\circ} \mathrm{C}$ ) were not observed in this study, it should be noted that when this event occurs during grain filling there is a change in the composition of the accumulated protein, and this negatively affects the $\mathrm{W}$. This occurs because heat stress increases the Gliadins (GLI)/
Glutenins (GLU) ratio, because the accumulation of GLU decreases more than GLI, impairing the quality of dough produced (STONE et al., 1997). Moreover, high temperature decreases the synthesis of highmolecular-weight glutenins (HMW), resulting in lower W (CORBELINI et al., 1998).

Table 4. Comparison of mean gluten strength $\left(10^{-4} \mathrm{~J}\right)$, elasticity $(\mathrm{mm})$, extensibility $(\mathrm{mm}), \mathrm{P} / \mathrm{L}$, and absorption of water (\%) in the interaction between cultivars and environments and mean stability ( $\mathrm{min}$ ) of dough for the effects of cultivars and environments.

\begin{tabular}{|c|c|c|c|c|}
\hline \multirow{3}{*}{ Cultivars } & \multicolumn{2}{|c|}{ Gluten strength (W) } & \multicolumn{2}{|c|}{ Elasticity $(\mathrm{P})$} \\
\hline & \multicolumn{2}{|c|}{ Environments ${ }^{1}$} & \multicolumn{2}{|c|}{ Environments } \\
\hline & $\mathrm{A} 1$ & A2 & A1 & A2 \\
\hline IPR Catuara TM & $491 \mathrm{aA}$ & $484 \mathrm{aA}$ & $129 \mathrm{aA}$ & $128 \mathrm{aA}$ \\
\hline BRS Gaivota & $372 \mathrm{aB}$ & $290 \mathrm{bB}$ & $107 \mathrm{aB}$ & 89 bB \\
\hline Quartzo & $270 \mathrm{aC}$ & $308 \mathrm{aB}$ & $136 \mathrm{aA}$ & $107 \mathrm{bB}$ \\
\hline CD 120 & $207 \mathrm{aC}$ & $208 \mathrm{aC}$ & $71 \mathrm{aC}$ & $55 \mathrm{bC}$ \\
\hline \multirow{3}{*}{ Cultivars } & \multicolumn{2}{|c|}{ Extensibility (L) } & \multicolumn{2}{|c|}{$\mathrm{P} / \mathrm{L}$} \\
\hline & \multicolumn{2}{|c|}{ Environments } & \multicolumn{2}{|c|}{ Environments } \\
\hline & A1 & $\mathrm{A} 2$ & A1 & $\mathrm{A} 2$ \\
\hline IPR Catuara TM & $111 \mathrm{aA}$ & $123 \mathrm{aA}$ & $1.19 \mathrm{aB}$ & $1.05 \mathrm{aAB}$ \\
\hline BRS Gaivota & $101 \mathrm{aAB}$ & $117 \mathrm{aA}$ & $1.09 \mathrm{aB}$ & $0.77 \mathrm{aBC}$ \\
\hline Quartzo & $51 \mathrm{bC}$ & $89 \mathrm{aB}$ & $2.77 \mathrm{aA}$ & $1.30 \mathrm{bA}$ \\
\hline CD 120 & $74 \mathrm{bBC}$ & $131 \mathrm{aA}$ & $1.04 \mathrm{aB}$ & $0.43 \mathrm{bC}$ \\
\hline \multicolumn{5}{|c|}{ Absorption (AAM) } \\
\hline \multirow[t]{2}{*}{ Cultivars } & \multicolumn{2}{|c|}{ Environments } & \multirow{2}{*}{\multicolumn{2}{|c|}{ Stability (EST) }} \\
\hline & A1 & $\mathrm{A} 2$ & & \\
\hline IPR Catuara TM & $64 \mathrm{bA}$ & $66 \mathrm{aA}$ & \multicolumn{2}{|c|}{$21 \mathrm{~A}$} \\
\hline BRS Gaivota & $64 \mathrm{aA}$ & $63 \mathrm{aB}$ & \multicolumn{2}{|c|}{$11 \mathrm{~B}$} \\
\hline Quartzo & $61 \mathrm{aB}$ & $61 \mathrm{aB}$ & \multicolumn{2}{|c|}{$14.4 \mathrm{AB}$} \\
\hline CD 120 & $52 \mathrm{bC}$ & $55 \mathrm{aC}$ & \multicolumn{2}{|c|}{$13.8 \mathrm{~B}$} \\
\hline \multicolumn{3}{|c|}{ Environments } & \multicolumn{2}{|c|}{ Stability (EST) } \\
\hline \multicolumn{3}{|c|}{$\mathrm{A} 1$} & \multicolumn{2}{|c|}{$20.5 \mathrm{~A}$} \\
\hline \multicolumn{3}{|c|}{$\mathrm{A} 2$} & \multicolumn{2}{|c|}{$9.3 \mathrm{~B}$} \\
\hline
\end{tabular}

Legend: W, gluten strength; P, tenacity; L, extensibility; AAM, dough water absorption; EST, dough stability. ${ }^{1} \mathrm{~A} 1$, Environment 1 (Londrina, Year 1); A2, Environment 2 (Londrina, Year 2). Lowercase letters represent comparisons within rows, and uppercase letters represent comparisons within columns. Medians followed by the same letter did not differ by the Tukey test at $5 \%$.

According to the results of the relationship between $\mathrm{P}$ and $\mathrm{L}$, the cultivars IPR Catuara TM and BRS Gaivota were not influenced by the environment. The flour that presented values of $\mathrm{P} / \mathrm{L}$ below 0.60 may be considered extensible gluten, from 0.61 to 1.20 are gluten balanced, and values of $\mathrm{P} / \mathrm{L}$ above 1.21 are tenacious gluten (GERMANI, 2007). The cultivar Quartzo presented tenacious 
gluten, which means that the flour of this cultivar is indicated for dough. The balanced gluten of the cultivars IPR Catuara TM and BRS Gaivota enable its use for making bread. Finally, the cultivar CD 120, in general, presented extensible gluten and could be used in cookies.
The data obtained by the joint analysis between the wheat cultivars revealed a significant correlation only between SSD and TP (Figure 2). Luo et al. (2000) stated that the quality of wheat flour cannot be evaluated by a single quality parameter because several factors influence the results.

Figure 2. Numerical and visual joint correlation between wheat cultivars in different forms of nitrogen management and environmental conditions for alveograph and farinograph.

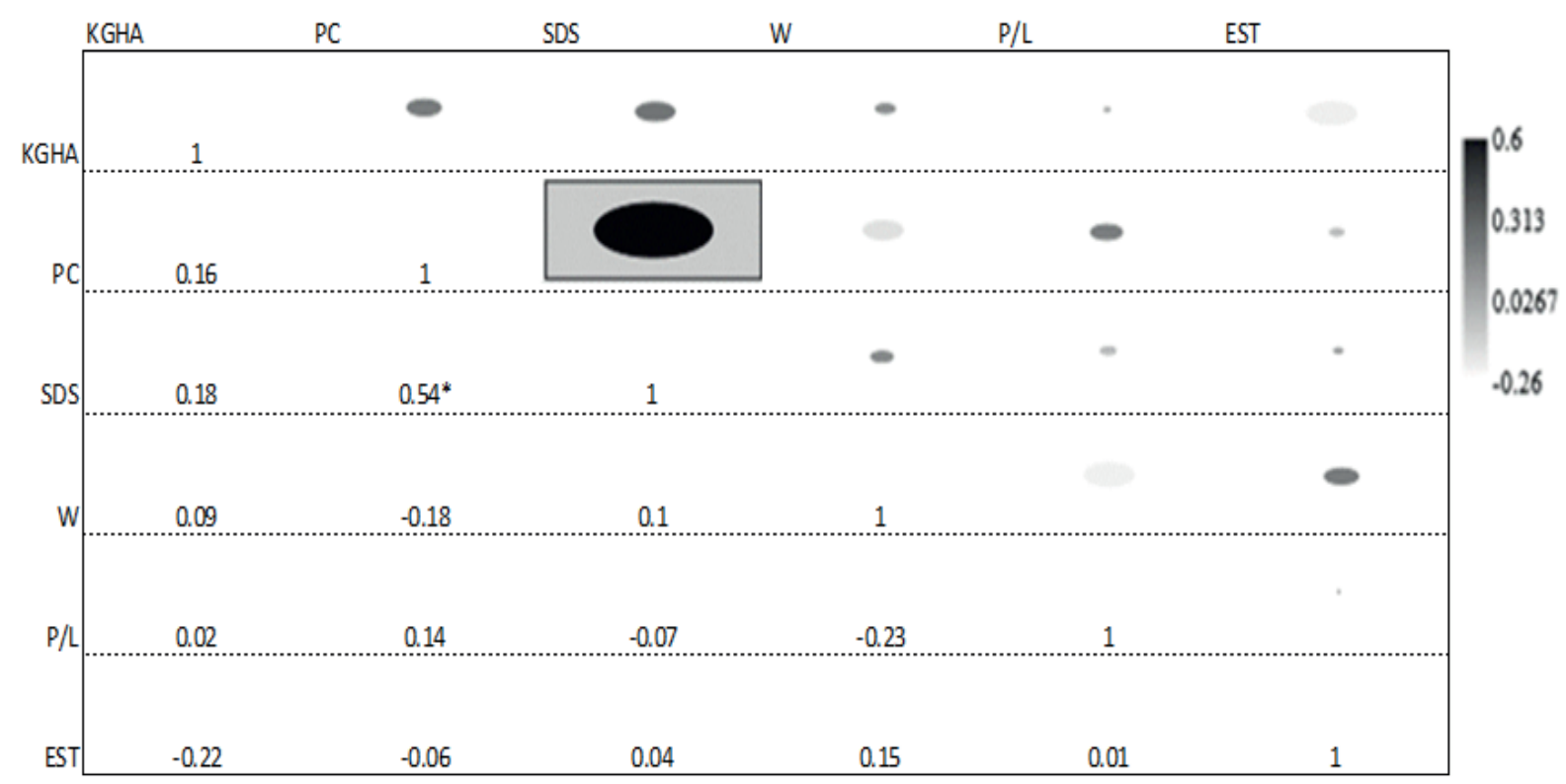

Legend: W, gluten strength; P, tenacity; L, extensibility; AAM, dough water absorption; EST, dough stability; PC, protein content; SDS, sodium dodecyl sulfate.

The results of the farinograph indicated that the AAM was influenced by the interaction between genotypes and environments (Table 3). Only the cultivars IPR Catuara TM and CD 120 had AAM influenced by the environment, and environment 2 provided the highest AAM (Table 3). The cultivars with the highest AAM were IPR Catuara (A1 and A2) and BRS Gaivota (A1), whereas the lowest AAM was observed for the cultivar CD 120. The most common parameters of the farinograph curves were to estimate the AAM and the stability of the dough. In general, a high AAM is dependent on the TP of the flour; however, it was not always associated with high technological quality (FOWLER; KOVACS, 2004).
The dough stability is recognized as an indicator of greater resistance to kneading and better technological quality. In this study, the EST was influenced by the effect of cultivars and the environments (Table 3). The cultivars IPR Catuara TM and Quartzo presented the highest EST, with this value being in the A1 environment (Table 4).

However, these results do not necessarily indicate that both cultivars have an effectively high EST because this feature depends on TP (FOWLER; KOVACS, 2004). Nevertheless, no correlation was observed between the EST and TP. Fowler and Kovacs (2004) reported nonlinear models between TP and EST for cultivars with TP between $7 \%$ and 
$17 \%$, whereas in this study we observed values between $15 \%$ and $23 \%$ for $\mathrm{TP}$, which may explain the absence of a linear correlation.

$\mathrm{W}$ was used to indicate the ability of flour to undergo mechanical treatment when mixed with water. The results in Table 4 indicate that the cultivar Quartzo may not be suitable for cultivation in the region of Londrina when the final use of the flour is for baking bread because of the lack of balance in the viscoelastic properties at low $\mathrm{W}$ values.

Grain yield showed no correlation with any of the parameters evaluated. In previous studies, there have been reports of a negative relationship between grain yield and TP (GUARDA et al., 2004; ŠÍP et al., 2013), with a concomitant increase in TP and productivity of grains (PINNOW et al., 2013) and the absence of a correlation (BORDES et al., 2008). Therefore, the absence of correlation between grain yield and TP can be explained by the effects of environment, genotype, and cultural practices (PINNOW et al., 2013; ŠÍP et al., 2013), thus, negating the possibility of generalizing a correlation between TP and grain yield.

\section{Conclusions}

Under the conditions in which the study was conducted, we conclude the following:

The fertilization of coverage did not influence the industrial quality parameters.

Productivity was not correlated with the gluten strength, tenacity, extensibility, water absorption of dough, or dough stability.

The interaction between genotypes and environments influenced the alveograph parameters and water absorption of dough.

\section{References}

BORDES, J.; BRANLARD, G.; OURY, F. X.; CHARMET, G.; BALFOURIER, F. Agronomic characteristics, grain quality and flour rheology of 372 bread wheat in a worldwide core collection. Journal of Cereal Science, Pretoria, v. 48, n. 3, p. 569-579, 2008. DOI: 10.1016/j.jcs.2008.05.005

CAZETTA, D. A.; FORNASIERI FILHO, D.; ARF, O.; GERMANI, R. Qualidade industrial de cultivares de trigo e triticale submetidos à adubação nitrogenada no sistema de plantio direto. Bragantia, Campinas, v. 67, n. 3, p. 741750, 2008. DOI: 10.1590/S0006-87052008000300024.

COMPANHIA NACIONAL DE ABASTECIMENTO CONAB.Boletim de grãos maio 2018. 2018. Disponível em: https://www.conab.gov.br/info-agro/safras/graos. Acesso em: 26 jul. de 2018.

CORBELINI, M.; MAZZA, L.; CIAFFI, M.; LAFIANDRA, D.; BORGHI, G. Effect of heat shock during grain filling on protein composition and technological quality of wheats. Euphytica, Wageningen, v. 100, n. 2, p. 147-154, 1998. DOI: 10.1023/A:101835330

DICK, J. W.; QUICK, J. S. A modified screening test for rapid estimation of gluten strength in early generation durum wheat breeding lines. Cereal Chemistry, Sydney, v. 60, n. 4 , p. $315-318,1983$.

FOWLER, D. B.; KOVACS, M. I. P. Influence of protein concentration on farinograph absorption, mixing requirements and mixing tolerance. Canadian Journal of Plant Science, Ottawa, v. 84, n. 3, p. 765-772, 2004. DOI: $10.4141 / \mathrm{P} 03-148$

GAJU, O.; REYNOLDS, M. P.; SPARKES, D. L.; FOULKES, M. J. Relationships between large-spike phenotype, grain number, and yield potencial in spring wheat. Crop Science, Madson, v. 49, n. 3, p. 961-973, 2009. DOI: $10.2135 /$ cropsci2008.05.0285

GARRIDO-LESTACHE, E.; LÓPEZ-BELLIDO, R. J.; LÓPEZ-BELLIDO, L. Effect of $\mathrm{N}$ rate, timing and splitting and $\mathrm{N}$ type on bread-making quality in hard red spring wheat under rainfed Mediterranean conditions. Field Crops Research, California, v. 85, n. 2-3, p. 213236, 2004. DOI: 10.1016/S0378-4290(03)00167-9

GAZOLA, D.; ZUCARELI, C.; SILVA, R. R. Aplicação foliar de aminoácidos como suplemento à adubação nitrogenada em cultivares de trigo. Cientifica. Jaboticabal, v. 45, n. 2, p. 182-189, 2017. DOI: 10.15361/1984-5529.2017v45n2p182-189

GERMANI, R. Características dos grãos e farinhas de trigo e avaliações de suas qualidades. Rio de Janeiro: Embrapa, Agroindústria de Alimentos, 2007. 129 p. Disponível em: https://pt.scribd.com/doc/ 59543855/ APOSTILA-EMBRAPA. Acesso em: 26 jul. 2018. 
GUARDA, G.; PADOVAN, S.; DELOGU, G. Grain yield, nitrogen-use efficiency and baking quality of old and modern Italian bread-wheat cultivars grown at different nitrogen levels. European Journal of Agronomy, Amsterdam, v. 21, p. 181-192, 2004. DOI: $10.1016 / j$. eja.2003.08.001

HAJHEIDARI, M.; EIVAZI, A.; BUCHANAN, B. B.; WONG, J. H.; MAJIDI, I.; SALEKDEH, G. H. Proteomics uncovers a role for redox in drought tolerance in wheat. Journal of Proteome Research, California, v. 6, n. 4, p. 1451-1460, 2007. DOI: 10.1021/pr060570j

HRISTOV， N.; MLADENOV， N.; DJURIC， V.; KONDIC-SPIKA, A.; MARJANOVIC-JEROMELA, A.; SIMIC, D. Genotype by environment interactions in wheat quality breeding programs in southeast Europe. Euphytica, Wageningen, v. 174, n. 3, p. 315-324, 2010. DOI: $10.1007 / \mathrm{s} 10681-009-0100-8$

LABUSCHAGNE, M.T.; ELAGO, O.; KOEN, E. The influence of temperature extremes on some quality and starch characteristics in bread, biscuit and durum wheat. Journal of Cereal Science, Pretoria, v. 49, n. 2, p. 184189, 2009. DOI: 10.1016/j.jcs.2008.09.001

LUO, C.; BRANLARD, G.; GRIFFIN, W. B.; McNEIL, D. L. The effect of nitrogen and sulphur fertilization and their interaction with genotype on wheat glutenins and quality parameters. Journal of Cereal Science, Pretoria, v. 31, n. 2, p. 185-194, 2000. DOI: 10.1006/jcrs. 1999.0298

PINNOW, C.; BENIN, G.; VIOLA, R.; SILVA, C. L. da; GUTKOSKI, L. C.; CASSOL, L.C. Qualidade industrial do trigo em resposta à adubação verde e doses de nitrogênio. Bragantia, Campinas, v. 72, n. 1, p. 20-28, 2013. DOI: $10.1590 / \mathrm{S} 0006-87052013005000019$

R DEVELOPMENT CORE TEAM. R: a language and environment for statistical computing. R Foundation for Statistical Computing Vienna, Austria. 2009.
SANTOS, H. G. dos. JACOMINE, P. K. T.; ANJOS, L. H. C. dos; OLIVEIRA, V. A. de; OLIVEIRA, J. B. de; COELHO, M. R.; LUMBRERAS, J. F.; CUNHA, T. J. F. (Ed.). Sistema brasileiro de classificação de solos. 3. ed. Brasília: Embrapa Solos, 2013. 353 p.

ŠÍP, V.; VAVERA, R.; CHRPOVÁ, J.; KUSÁ, H.; RůžK, P. Winter wheat and quality related to tillage practice, input level and environmental conditions. Soil \& Tillage Reserarch, Kiel, v. 132, n. 1, p. 77-85, 2013. DOI: 10.1016/j.still.2013.05.002

STONE, P. J.; GRAS, P. W.; NICHOLAS, M. E. The influence of recovery temperature on the effects of a brief heat shock on wheat. III. Grain protein composition and dough-properties. Journal of Cereal Science, Pretoria, v. 25, n. 2, p. 129-141, 1997. DOI: 10.1006/jcrs. 1996.0080

TRIBOI, E.; TRIBOI-BLONDEL, A. M. Productivity and grain or seed composition: a new approach to an old problem. European Journal of Agronomy, Amsterdam, v. 16, n., p. 163-186, 2002.

VARGA, B.; SVECNJAK, Z. The effect of late-season urea spraying on grain yield and quality of winter wheat cultivars under low and high basal nitrogen fertilization. Field Crops Research, California, v. 96, n. 1, p. 125-132, 2006. DOI: 10.1016/j.fcr.2005.06.001

XING, Z. C.; RONG, H. M.; LIN, W. Z.; FU, W. Y.; QI, L. Effects of different water availability at post-anthesis stage on grain nutrition and quality in strong-gluten winter wheat. Comptes Rendus Biologies, Paris, v. 332, n. 8, p. 759-763, 2009. DOI: 10.1016/j.crvi.2009.03.003

YUE, H.; JIANG, D.; DAI, T.; QIN, X.; JING, Q.; $\mathrm{CAO}, \mathrm{W}$. Effect of nitrogen application rate on content of glutenin macropolymer and high molecular weight glutenin subunits in grains of two winter wheat cultivars. Journal of Cereal Science, Pretoria, v. 45, n. 3, p. 248256, 2007. DOI: 10.1016/j.jcs.2006.09.003 